\title{
Discrepancies of surface temperature trends in the CMIP5 simulations and observations on the global and regional scales
}

L. Zhao ${ }^{1,2}$, J. $\mathbf{X u}^{2}$, and A. M. Powell Jr. ${ }^{3}$

${ }^{1}$ Nanjing University of Information Science and Technology, Nanjing, China

${ }^{2}$ Environmental Science and Technological Center, College of Science, George Mason University, Fairfax, Virginia, USA

${ }^{3}$ NOAA/NESDIS/STAR, College Park, Maryland, USA

Received: 3 October 2013 - Accepted: 22 October 2013 - Published: 1 November 2013

Correspondence to: J. Xu (jxu14@gmu.edu)

Published by Copernicus Publications on behalf of the European Geosciences Union.

Discrepancies of surface temperature trends in the CMIP5

simulations

L. Zhao et al.

\section{Title Page}

\section{Full Screen / Esc}

Printer-friendly Version

Interactive Discussion 


\section{Abstract}

Using the fifth Coupled Model Intercomparison Project (CMIP5) model simulations and two observational datasets, the surface temperature trends and their discrepancies have been examined. The temporal-spatial characteristics for the surface temperature 5 trends are discussed. Different from a constant estimated linear trend for the entire simulation period of 1850-2012, a dynamical trend using running linear least squares fitting with the moving $10 \mathrm{yr}$ time windows are calculated. The results show that the CMIP5 model simulations are generally in good agreement with the observational measurements for the global scale warming, but the temperature trends depend on the temporal change and the regional differences. Generally, contrary to the small discrepancies on the global scale, the large discrepancies are observed in the south- and north-polar regions and other sub-regions.

\section{Introduction}

The fifth Coupled Model Intercomparison Project (CMIP5) provided quantitative 15 datasets for estimating climate change based on a suite of climate models (Taylor et al., 2012). The new climate model products are considered predictions of future climate change, which relies heavily on how well the climate models simulate historical climate change. Each model's reliability impacts the credibility of that model's predictions. Consequently, evaluating climate model results using observational data sets is necessary to understand the capabilities and limitations of climate change simulations.

The surface temperature trends are a very important component to investigate for understanding the state of the global climate. The trends receive a great deal of attention in the climate change community (Hansen, 2001, 2010; Brohan et al., 2006; and many others), because these trends, anomalies, and variations provide evidence of global warming and the possibility of human influence on climate (Intergovernmental Panel on Climate Change, IPCC). However, based on previous studies, two questions

\section{CPD}

$9,6161-6178,2013$

Discrepancies of surface temperature trends in the CMIP5 simulations

L. Zhao et al.

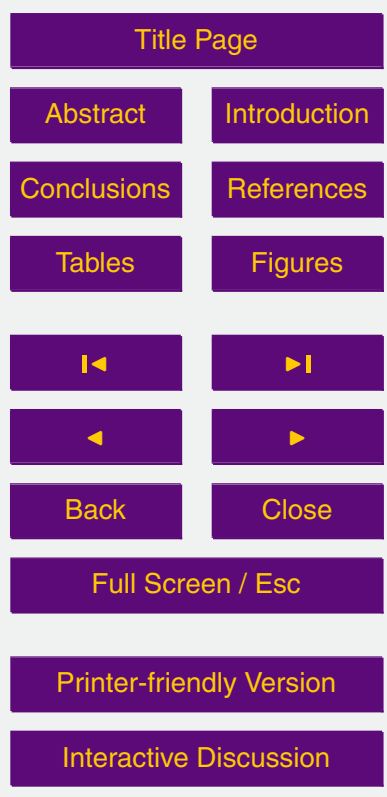

Interactive Discussion 
have not yet been clearly answered, (1) one is how the temperature trends depend on temporal changes, and (2) another is how discrepancies in the different data sources influence the temperature trends, such as climate model simulations and the different kinds of observations.

5 Previous studies typically used the overall trends to assess the long-term behavior of temperature time series (Hansen, 1987; Mitchell et al., 2013; Xu and Powell, 2010, 2013; Powell et al., 2012). However, temperature trends change with time period and real time series are generally not well fitted by a straight line because climate may also change abruptly (Alley et al., 2003; Hare and Mantua, 2000). Therefore, the overall 10 linear trend of a temperature time series may conceal some of the temporal characteristics of the temperature change, which is closely linked to changes in dynamic and radiative processes in the atmosphere. To better characterize the temporal change of temperature trends, the annual mean temperature time series are analyzed using the methodology of running linear least squares fits, which can reveal important features 15 of the data, such as long term trends, localized changes and when an abrupt change occurred.

Recently, discrepancies between observations and climate model simulations in the tropical zone have sparked much research. Santer et al. (2005) investigated the altitude dependence of temperature trends in the tropical zone. They compared available observations with 19 of the IPCC CMIP3 models and suggested that any disparities between models and observations are due to residual errors in the observational datasets. From a study of several independent observational datasets, Douglass et al. (2004) confirmed that the disparity was real and arose mostly in the tropical zone. Douglass et al. (2007) examined tropospheric temperature trends based on 67 runs from 22 "Climate of the 20th Century" model simulations and found that the model simulated and observed temperature trends are in disagreement in most of the tropical troposphere. Also, Mitchell et al. (2013) found that the tropical temperature trends in the period of 1979-2008 are not consistent with observations throughout the depth of the troposphere, and this primarily stems from a poor simulation of the surface temperature

\section{CPD}

$9,6161-6178,2013$

Discrepancies of surface temperature trends in the CMIP5 simulations

L. Zhao et al.

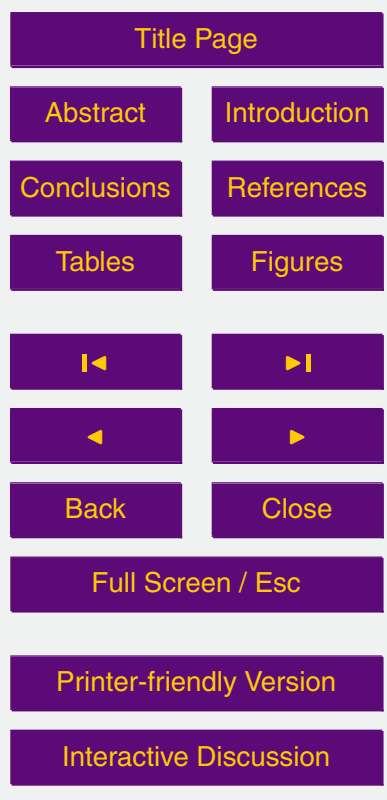

Interactive Discussion 
trends. In this paper, we will investigate both the global and regional characterization of surface temperature trend discrepancies rather than concentrating on tropical zone. This characterization can provide a better understanding of the capabilities and limitations of the climate models in representing climate change on global and regional 5 scales.

For this purpose, the CMIP5 model simulations and observations including HadCRUT4 and GISS reconstructed data sets are compared to characterize the global and regional surface temperature changes since 1850. The goal is to answer the above two questions about the temperature trends in the CMIP5 simulations and other observa10 tions. Section 2 describes the datasets and methodologies. The temporal analysis of different geographical regions and the spatial variation pattern of the global temperature trend are presented in Sect. 3. Section 4 provides a final summary and discussion.

\section{Data and methodology}

\subsection{Observations}

15 To assess the global surface mean temperature changes in the CMIP5 climate model simulations, two observational datasets have been used for comparison: (1) the new surface temperature data HadCRUT4 is created by the Met Office Hadley Centre and the Climatic Research Unit at the University of East Anglia (Jones, 1994; Brohan et al., 2006). (2) The new GISS analysis dataset is developed by the National Aeronautics and Space Administration's (NASA) Goddard Institute for Space Studies (GISS) (Hansen et al., 2001, 2010).

\subsection{The CMIP5 model simulations}

The sixteen (16) CMIP5 model simulations are selected from the 22 available groups' historical run in the IPCC Model archive at the Program for Climate Model Diagnosis and Intercomparison (PCMDI) (Taylor et al., 2012). The detailed information about the

\section{4}

\section{CPD}

$9,6161-6178,2013$

Discrepancies of surface temperature trends in the CMIP5

simulations

L. Zhao et al.

Title Page

Abstract Introduction

Conclusions

Tables References Figures

14

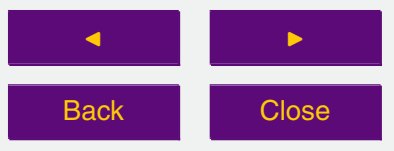

Full Screen / Esc

Printer-friendly Version

Interactive Discussion 
16 models can be found in the Table 1. The "historical" run is forced by observed atmospheric composition changes (reflecting both anthropogenic and natural sources) including time evolving land cover. Each of the 16 models have been run with multiple ensemble members with between one and nine simulations, and the ensemble mean 5 is used here for each model.

Most of the CMIP5 model datasets spanned the period from 1850 through 2005 (Table 1). GISS begins in 1880 and HADCRUT4 begins in 1850, both of them end in 2012.

\subsection{Running linear least square fitting}

10 Running linear least square fitting (L'Heureux et al., 2013) is a form of linear least squares analysis, which is used to estimate the temperature trends with a moving $10 \mathrm{yr}$ temporal window. Different from the traditional linear least squares fitting, in which the rate of trend is constant for the full study period, the running linear least squares fitting technique can provide more detailed information about the trend changes with time.

\section{Temporal changes of surface temperature trends}

\subsection{Global scales}

Figure 1 shows the running linear trends of surface temperature over the global (GL), Northern Hemisphere $(\mathrm{NH})$, Southern Hemisphere $(\mathrm{SH})$, Arctic $\left(60-90^{\circ} \mathrm{N}\right)$, Antarctic $\left(60-90^{\circ} \mathrm{S}\right)$ and the Tropics $\left(20^{\circ} \mathrm{S}-20^{\circ} \mathrm{N}\right)$. The grey region shows the temperature trend

20 range among the 16 CMIP5 simulations (minimum and maximum values are range borders). The supplementary figure (Fig. S1) shows the same data as in Fig. 1, but provides the time series of surface temperature averaged over each latitude and regions over land.

At the global scale (Fig. 1a), all the time series tend to capture the same broad fea25 tures of the warming trends, especially in the two periods with long term persistence

\section{CPD}

$9,6161-6178,2013$

Discrepancies of surface temperature trends in the CMIP5 simulations

L. Zhao et al.

Title Page 
of warming in the periods of 1910-1940 and 1970-2010. These warming trends are observed in both the observations and all model simulations, which is similar to the analysis in previous studies (Thompson et al., 2008). It is clear that the model simulations have much better agreement with observations in the $40 \mathrm{yr}$ after 1970, but the 5 simulated model warming started around $10 \mathrm{yr}$ earlier and ended $10 \mathrm{yr}$ later than the observed warming during another period $40 \mathrm{yr}$ before 1950. Of particular interest are the opposite trends found in the $\sim 10 \mathrm{yr}$ periods at about 1895, 1910, 1930 and 1950. In addition, more subtle differences indicate that almost all the models overestimated cooling in the observed record at around 1880 and 1965, and overestimated warming 10 near 1998.

Apparently, the running temperature trends over the Northern Hemisphere $(\mathrm{NH})$ show a similar temporal characteristic to the global mean in both the model simulations and observations (Fig. 1b). But these variations are quite different from the pattern in the Southern Hemisphere (SH) (Fig. 1c), in which the warming and cooling alternated 15 with around a $20 \mathrm{yr}$ periodic oscillation from 1875 to 1955 in the HadCRUT4 observations. Note that the model simulations did not show this feature. The results tell us that the simulations in the $\mathrm{SH}$ have worse temperature trend estimations than their counterparts in $\mathrm{NH}$ compared to the observations.

In the tropics, the temperature trends (Fig. 1d) show similar general trending with greater variability than shown as the global change. However, large trends are observed over both polar regions (Fig. 1e and f). It is clear that two extreme warming periods 1915-1925 and 1995-2005 appeared in the Arctic (Fig. 1e), and the warming trends in the Antarctic tend to decrease in the most recent $40 \mathrm{yr}$. This decrease is consistent with the opposing trends seen in the data between the $\mathrm{NH}$ and $\mathrm{SH}$ po25 Iar regions (Powell et al., 2013). In addition, big discrepancies can be found over the Antarctic before 1965.

It is obvious that the GISS observations (thick, red solid) shows good correspondence in the SH (Fig. 1C) and poor correspondence in the Antarctic (Fig. 1f), particularly prior to 1945.

\section{CPD}

9, 6161-6178, 2013

Discrepancies of surface temperature trends in the CMIP5 simulations

L. Zhao et al.

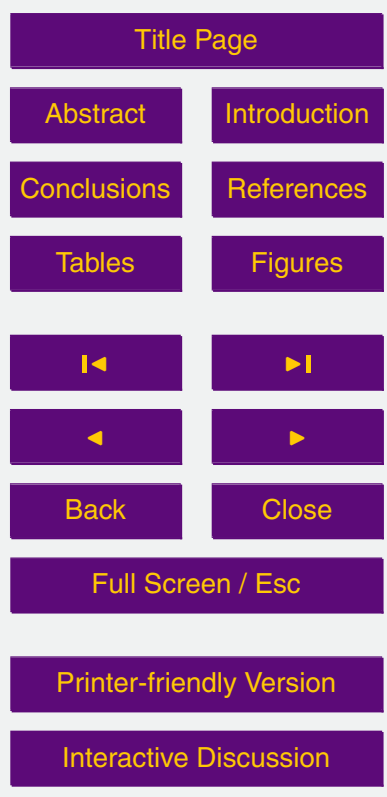




\subsection{Regional scales}

Figure 1g-n shows the running linear trends of surface temperature in 8 sub-regions over land. The 8 sub-regions are defined as follows: United States (US) (25-50 N, 70-

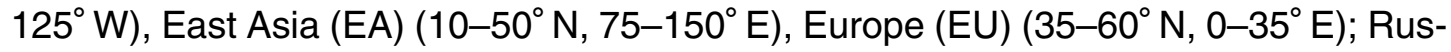
5 sia (RU) $\left(50-75^{\circ} \mathrm{N}, 35-160^{\circ} \mathrm{E}\right)$, Australia (AU) $\left(10-40^{\circ} \mathrm{S}, 110-155^{\circ} \mathrm{E}\right)$, South America (SA) $\left(55^{\circ} \mathrm{S}-10^{\circ} \mathrm{N}, 35-80^{\circ} \mathrm{W}\right)$, South Africa (SAF) $\left(0-30^{\circ} \mathrm{S}, 10-40^{\circ} \mathrm{E}\right)$ and North Africa (NAF) $\left(0-30^{\circ} \mathrm{N}, 10-40^{\circ} \mathrm{E}\right)$. Similar to the warming on the global scale, the second long term persistent period of warming occurred in 1970-2005 and is found over all 8 subregions. However, the trends exist with a significant difference over these sub-regions during the first long term period of persistent warming during the period of 1910-1940. For example, using the global scale warming starting in 1910 from the observational record, the temperature rise over EA, SA, AU and SAF are at the same time, but the temperature did not rise until $5 \mathrm{yr}$ later over US and RU. The EU did not show any warming until 1930. It is worth noting that the different model simulations seem to provide a consistent result although there are differences when compared against the observational record.

\subsection{Consistencies between simulations and observations}

Based on above results, it is not hard to find that the consistencies between model simulations and observations depend on the global or regional scales. In order to measure those discrepancies, the correlations are calculated between the HadCRUT4 dataset and the models. The results are shown in Table 2, where the correlation coefficient exceeding the threshold value of 0.4 is colored with yellow, it indicates that $16 \%$ or more of the variance in the datasets is explained by the correlation, and satisfies the statistical significant test at the $99 \%$ confidence level. From Table 2, one can see the correlation of the running trend time series between HadCRUT4 and GISS have a higher correlation coefficient except for the Antarctic zone, which reflects the strong consistency for the global and regional surface temperature change in the two observational

\section{CPD}

9, 6161-6178, 2013

Discrepancies of surface temperature trends in the CMIP5 simulations

L. Zhao et al.
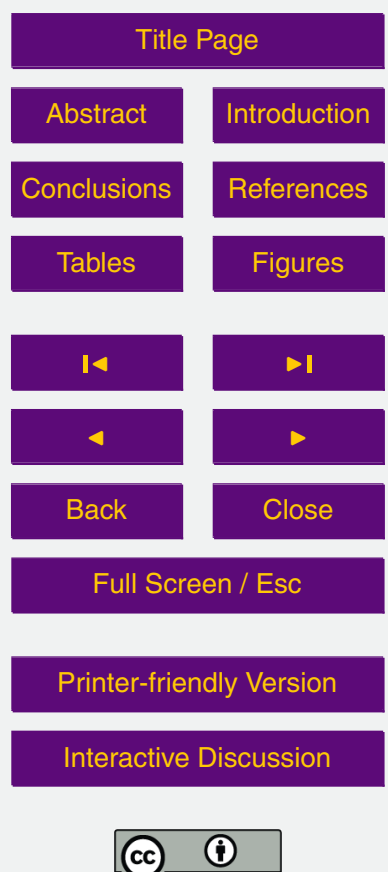
datasets (GISS and HadCRUT4). Using the HadCRUT4 dataset, the correlations were computed with the 16 CMIP5 model simulations. The results (Table 2) show that the correlations are sharply reduced from global to all sub-regions; the correlation coefficients vary greatly from one region to another region. Approximately $75 \%$ of the model 5 simulations achieved a relatively high correlation with observations at the global scale. It is also found that the $\mathrm{NH}$ correlation coefficient is higher than the $\mathrm{SH}$, tropic and both polar regions. This means that the CMIP5 models have much better performance in the $\mathrm{NH}$ (excluding the polar region) than their counterparts in the other areas. In addition, the relatively higher global correlation is mainly due to the $\mathrm{NH}$ contribution. Note that 10 the Antarctic is the worst region and may be due to the sparse surface observations, the higher elevations in Antarctica and other factors identified in the literature.

For the sub-regions, the correlation coefficient in East Asia is highest of all 8 regions, where there are also $75 \%$ of model simulations exceeding statistical significance test at $99 \%$ confidence level. At the middle-high latitudes, such as Russia, Europe, South 15 America, the model simulations have a relatively poor correlation with the other lowmiddle latitude regions.

It is not difficult to find that the correlations vary dramatically from one region to another region. The correlation analysis demonstrated that the CMIP5 simulations performance in the $\mathrm{NH}$ is better than $\mathrm{SH}$, the Arctic better than the Antarctic, and the lowmiddle region better than middle-high regions. An interesting fact is all CMIP5 models and observations show better consistency at global scale than the regional scale.

\subsection{Discrepancies in the simulations}

In order to quantify the discrepancies in the CMIP5 simulations, the ensemble spread is to represent the discrepancies based on the standard deviation among the 16 se25 lected models. The averaged spreads for the period of 1860-2005 derived from those model simulations are shown in Fig. 2. There are substantial variations at the global and regional scales. The trend spread changes from $\sim 0.1 \mathrm{Kdecade}^{-1}$ at the global scales to $\sim 0.3 \mathrm{Kdecade}^{-1}$ (or larger) at the regional scales. Both polar regions and

\section{CPD}

$9,6161-6178,2013$

Discrepancies of surface temperature trends in the CMIP5 simulations

L. Zhao et al.

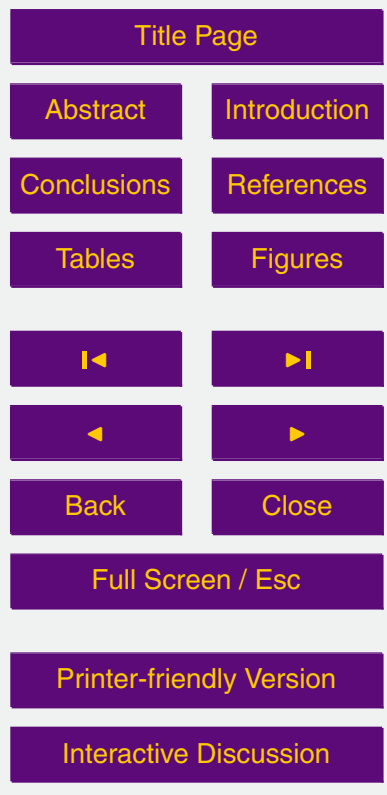

Interactive Discussion 
two high latitude regions including Russia and Europe show a large spread exceeding $0.25 \mathrm{Kdecade}^{-1}$, the value is double the amount of spread in the global mean and most other regions. The larger spread of the trend among the simulations reflects the influence of the different climate model systems on climate change estimates. Interestingly, 5 the Southern Hemisphere and tropical latitudes are found to have poor correlations with observations (Table 2), but their spreads among the 16 CMIP5 models show a comparatively small value. In other words, the high consistency among the model simulations in the SH or tropics cannot represent good performance for estimating climate change, because there are the large discrepancies with the observations. The poor correlation

10 with observations and the large spread among the model simulations observed in the polar regions and high latitude regions remind us that the CMIP5 simulations have serious issues over the these areas.

\section{Summary and discussion}

\subsection{Summary}

15 Based on the HadCRUT4 and NASA GISS surface temperature observations, the trends and discrepancies in CMIP5 model simulations have been examined. The results are summarized as follows:

On the temporal variation of the global temperature trends during the period 18502012, most of the CMIP5 model simulations captured the two long term persistent warming periods of 1910-1940 and 1970-2005. All 16 of the selected CMIP5 models and observations showed high consistency in the second warming period at both global and regional scales.

On the regional variation of the temperature trends, the CMIP5 model simulations reproduced a common feature with global surface warming, but the trends displayed

25 a significant discrepancy from one region to another region. The simulated warming rate is generally higher than the observations, particularly in the Arctic zone. And, some

\section{CPD}

$9,6161-6178,2013$

Discrepancies of surface temperature trends in the CMIP5 simulations

L. Zhao et al.

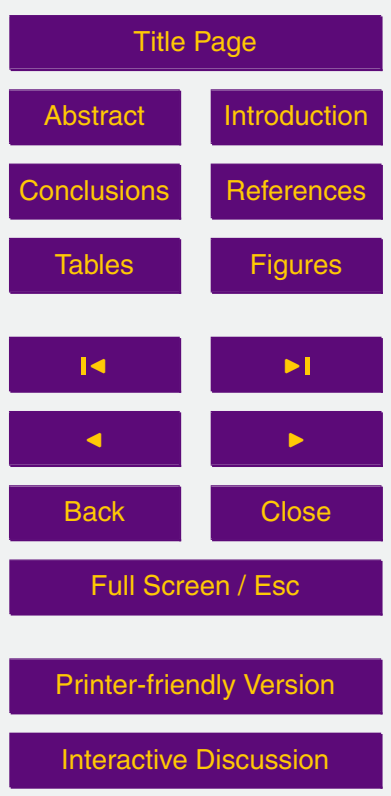

Interactive Discussion 
models show a strong cooling trend near 1905 and 1965, which exhibits an opposing result to the observations.

Generally, the temperature trends and spread show marked changes with region. The CMIP5 simulations overestimated the global warming compared to HadCRUT4 5 observations and remarkably overestimated the warming in the Arctic zone. The results show that most of the regions' spreads remain small, except the Antarctic, Arctic, Europe and Russia. The large spread shows that CMIP5 models have poor consistency in the polar regions and high latitudes.

\subsection{Discussion}

10 According to above analysis, it is worth noting that all selected CMIP5 model simulations showed high consistency with observations at the global scale. Generally, NH's consistency is better than $\mathrm{SH}$, and the sub-regions at the low-middle latitudes are better than the regions at the mid-high latitudes. A rather surprising result is that the $\mathrm{NH}$ correlation coefficient is remarkably higher than $\mathrm{SH}$, which shows the relatively higher 5 global correlation is mainly due to $\mathrm{NH}$ contribution.

Also the largest spread among models appears in the polar regions and high latitudes, which shows that CMIP5 models have poor consistency in these regions. The results give us to consider an important question: why is the consistency between model and observation better at low and middle latitudes in $\mathrm{NH}$ ? It may have somemeteorological stations are mainly located at low-middle latitudes on the land in the Northern Hemisphere (Brohan, 2006; Hansen, 1987). Thus, the high spatial distribution of observation stations in the $\mathrm{NH}$ provides a better result than that in the $\mathrm{SH}$ and the high latitudes.

\section{CPD}

$9,6161-6178,2013$

Discrepancies of surface temperature trends in the CMIP5 simulations

L. Zhao et al.

\section{Title Page}
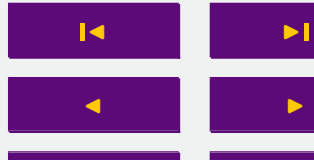

Back

Close 


\section{Supplementary material related to this article is available online at http://www.clim-past-discuss.net/9/6161/2013/cpd-9-6161-2013-supplement. pdf.}

Acknowledgements. The surface temperature data HadCRUT4 is created by the Met Office 5 Hadley Centre and the Climatic Research Unit at the University of East Anglia and the new GISS analysis dataset is developed by the National Aeronautics and Space Administration's (NASA) Goddard Institute for Space Studies (GISS). The Program for Climate Model Diagnosis and Intercomparison (PCMDI) collected and archived the model data. In addition, the first author get supported by the key program of the National Natural Science Foundation of China 10 (Grant 41230528). The authors would like to thank these agencies for providing the data and funding support.

This work was supported by the National Oceanic and Atmospheric Administration (NOAA), National Environmental Satellite, Data, and Information Service (NESDIS), Center for Satellite Applications and Research (STAR). The views, opinions, and findings contained in this publica15 tion are those of the authors and should not be considered an official NOAA or US Government position, policy, or decision.

\section{References}

Brohan, P., Kennedy, J. J., Harris, I., Tett, S. F. B., and Jones, P. D.: Uncertainty estimates in regional and global observed temperature changes: a new data set from 1850, J. Geophys. Res., 111, D12106, doi:10.1029/2005JD006548, 2006.

Douglass, D. H., Pearson, B. D., Singer, S. F., Knappenberger, P. C., and Michaels, P. J.: Disparity of tropospheric and surface temperature trends: new evidence, Geophys. Res. Lett., 31, L13207, doi:10.1029/2004GL020212, 2004.

Douglass, D. H., Christy, J. R., Pearson, B. D., and Singer, S. F.: A comparison of tropical tem25 perature trends with model predictions, Int. J. Climatol., 27, 206-223, doi:10.1002/joc.1651, 2007.

Hansen, J. E. and Lebedeff, S.: Global trends of measured surface air temperature, J. Geophys. Res., 92, 13345-13372, 1987.

\section{CPD}

$9,6161-6178,2013$

Discrepancies of surface temperature trends in the CMIP5 simulations

L. Zhao et al.

Title Page

Abstract Introduction

Conclusions References

Tables Figures
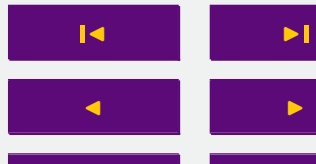

Back

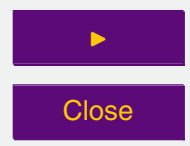

Full Screen / Esc

Printer-friendly Version

Interactive Discussion 
Hansen, J. E., Ruedy, R., Sato, M., Imhoff, M., Lawrence, W., Easterling, D., Peterson, T., and Karl, T.: A closer look at United States and global surface temperature change, J. Geophys. Res., 106, 23947-23963, doi:10.1029/2001JD000354, 2001.

Hansen, J. E., Ruedy, R., Sato, M., and Lo, K.: Global surface temperature change, Rev. Geophys., 48, RG4004, doi:10.1029/2010RG000345, 2010.

Jones, P. D.: Hemispheric surface air temperature variations: a re-analysis and an update to 1993, J. Climate, 7, 1794-1802, 1994.

Jones, P. D. and Moberg, A.: Hemispheric and large-scale surface air temperature variations: an extensive revision and an update to 2001, J. Climate, 16, 206-223, 2003.

10 L'Heureux, M. L., Lee, S., and Lyon, B.: Recent multidecadal strengthening of the Walker circulation across the tropical Pacific, Nat. Clim. Change, 3, 571-576, doi:10.1038/nclimate1840, 2013.

Mitchell, D. M., Thorne, P. W., Stott, P. A., and Gray, L. J.: Revisiting the controversial issue of tropical tropospheric temperature trends, Geophys. Res. Lett., 40, 2801-2806, 2013.

15 Powell Jr., A. M., Xu, J., Zou, C.-Z., and Zhao, L.: Stratospheric and tropospheric SSU/MSU temperature trends and compared to reanalyses and IPCC CMIP5 simulations in 1979-2005, Atmos. Chem. Phys. Discuss., 13, 3957-3992, doi:10.5194/acpd-13-3957-2013, 2012.

Rayner, N. A., Brohan, P., Parker, D. E., Folland, C. K., Kennedy, J. J., Vanicek, M., Ansell, T., and Tett, S. F. B.: Improved analyses of changes and uncertainties in marine temperature measured in situ since the mid-nineteenth century: the HadSST2 dataset, J. Climate, 19, 446-469, 2006.

Santer, B. D., Wigley, T. M. L., Mears, C., Wentz, F. J., Klein, S. A., Seidel, D. J., Taylor, K. E., Thorne, P. W., Wehner, M. F., Gleckler, P. J., Boyle, J. S., Collins, W. D., Dixon, K. W., Doutriaux, C., Free, M., Fu, Q., Hansen, J. E., Jones, G. S., Ruedy, R., Karl, T. R., Lanzante, J. R., Meehl, G. A., Ramaswamy, V., Russell, G., and Schmidt, G. A.: Amplification of surface temperature trends and variability in the tropical atmosphere, Science, 309, 1551-1555, 2005.

Taylor, K. E., Stouffer, R. J., and Meehl, G. A.: An overview of CMIP5 and the experiment design, B. Am. Meteorol. Soc., 93, 485-498, doi:10.1175/BAMS-D-11-00094.1, 2012.

30 Thompson, D. W. J., Kennedy, J. J., Wallace, J. M., and Jones, P. D.: A large discontinuity in the mid-twentieth century in observed global-mean surface temperature, Nature, 453, 646-649, 2008.

\section{CPD}

9, 6161-6178, 2013

Discrepancies of surface temperature trends in the CMIP5 simulations

L. Zhao et al.

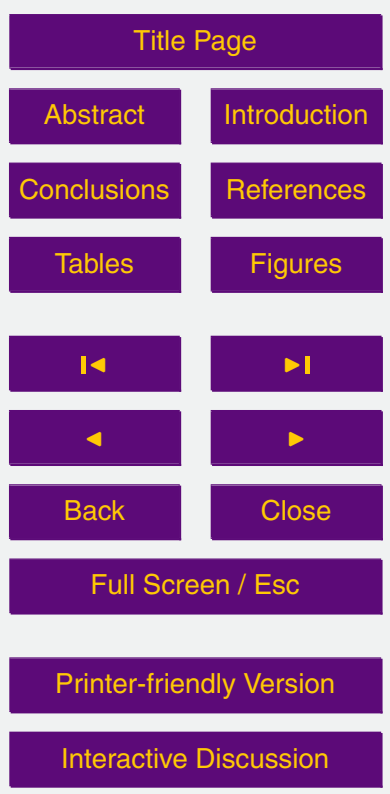


Xu, J. and Powell, A.: Ensemble spread and its implication for the evaluation of temperature trends from multiple radiosondes and reanalyses products, Geophys. Res. Lett., 37, L17704, doi:10.1029/2010GL044300, 2010.

Xu, J., Powell Jr., A. M., and Zhao, L.: Intercomparison of temperature trends in IPCC CMIP5 5 simulations with observations, reanalyses and CMIP3 models, Geosci. Model Dev., 6, 17051714, doi:10.5194/gmd-6-1705-2013, 2013.

\section{CPD}

9, 6161-6178, 2013

\section{Discrepancies of} surface temperature trends in the CMIP5 simulations

L. Zhao et al.

\section{Title Page}

\section{Abstract}

Introduction

Conclusions

References

Tables

Figures

14

4

Back

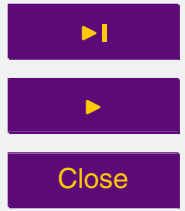

Full Screen / Esc

Printer-friendly Version

Interactive Discussion 
Table 1. The CMIP5/IPCC data sets and selected information.

\begin{tabular}{|c|c|c|c|c|}
\hline IPCC I.D. & Model & Center and location & Forcing & Time period \\
\hline HadCM3 & land-surface/vegetation, ocean, atmosphere & Met Office Hadley Centre & $\mathrm{GHG}, \mathrm{Oz}, \mathrm{SA}, \mathrm{SI}, \mathrm{VI}$ & $1860-2005$ \\
\hline HadGEM2-AO & atmosphere; sea ice; land atm & Met Office Hadley Centre & $\begin{array}{l}\text { Nat, Ant, GHG, SA, Oz, } \\
\text { LU, SI, VI, SS, Ds, BC, } \\
\text { MD, OC' }\end{array}$ & $1860-2005$ \\
\hline HadGEM2-ES & $\begin{array}{l}\text { Atmosphere, ocean, land-surface/vegetation, } \\
\text { tropospheric chemistry, ocean biogeochem- } \\
\text { istry }\end{array}$ & Met Office Hadley Centre & $\begin{array}{l}\text { GHG, SA, Oz, LU, SI, VI, } \\
\text { BC, OC }\end{array}$ & $1860-2005$ \\
\hline MIROC-ESM & $\begin{array}{l}\text { atmosphere; ocean; sea ice; land; } \\
\text { aerosols; ocean-biogeochemistry; land- } \\
\text { biogeochemistry }\end{array}$ & $\begin{array}{l}\text { Japan Agency for Marine-Earth Sci- } \\
\text { ence and Technology }\end{array}$ & $\begin{array}{l}\text { GHG, SA, Oz, LU, SI, VI, } \\
\text { MD, BC, OC }\end{array}$ & $1850-2005$ \\
\hline MIROC5 & atmosphere; ocean; sea ice; land & $\begin{array}{l}\text { The University of Tokyo, Japan Na- } \\
\text { tional Institute for Environmental Stud- } \\
\text { ies and Japan Agency for Marine-Earth } \\
\text { Science and Technology }\end{array}$ & $\begin{array}{l}\text { GHG, SA, Oz, LU, SI, VI, } \\
\text { SS, Ds, BC, MD, OC }\end{array}$ & $1850-2012$ \\
\hline Bcc-Csm1 & atmosphere; ocean; sea ice; land & $\begin{array}{l}\text { Beijing Climate Center, China Meteo- } \\
\text { rological Administration }\end{array}$ & $\begin{array}{l}\text { 'Nat Ant GHG SD Oz SI VI } \\
\text { SS Ds BC OC }\end{array}$ & $1850-2012$ \\
\hline $\begin{array}{l}\text { CESM1-CAM5- } \\
\text { 1-FV2 }\end{array}$ & atmosphere; ocean; sea ice; land & $\begin{array}{l}\text { National Science Foundation, Depart- } \\
\text { ment of Energy, National Center for At- } \\
\text { mospheric Research }\end{array}$ & GHG, SA, SI, VI, BC, OC & $1850-2005$ \\
\hline CNRM-CM5 & atmosphere; ocean; sea ice; land & $\begin{array}{l}\text { Centre National de Recherches Me- } \\
\text { teorologiques/Centre Europeen de } \\
\text { Recherche et Formation Avancees en } \\
\text { Calcul Scientifique }\end{array}$ & GHG, SA, SI, VI, BC, OC & $1850-2005$ \\
\hline $\begin{array}{l}\text { GFDL-CM3 } \\
\text { GFDL-ESM2G }\end{array}$ & atmosphere; ocean; sea ice; land, iceberge & $\begin{array}{l}\text { Geophysical Fluid Dynamics Labora- } \\
\text { tory }\end{array}$ & $\begin{array}{l}\text { GHG, SA, Oz, LU, SI, VI, } \\
\text { SS, BC, MD, OC }\end{array}$ & $1860-2005$ \\
\hline $\begin{array}{l}\text { GISS-E2-H } \\
\text { GISS-E2-R }\end{array}$ & atmosphere; ocean; sea ice; land surface & $\begin{array}{l}\text { NASA Goddard Institute for Space } \\
\text { Studies }\end{array}$ & $\begin{array}{l}\text { GHG, LU, SI, VI, BC, OC, } \\
\text { SA, Oz }\end{array}$ & $1850-2005$ \\
\hline $\begin{array}{l}\text { MPI-ESM-LR } \\
\text { MPI-ESM-P }\end{array}$ & atmosphere; ocean; sea ice; land, marine & Max Planck Institute for Meteorology & GHG Oz SD SI VI LU & $1850-2005$ \\
\hline MRI-CGCM3 & atmosphere; ocean; sea ice; land; aerosols & $\begin{array}{l}\text { MRI (Meteorological Research Insti- } \\
\text { tute, Tsukuba, Japan) }\end{array}$ & $\begin{array}{l}\text { GHG, SA, Oz, LU, SI, VI, } \\
\text { BC, OC }\end{array}$ & $1850-2005$ \\
\hline IPSL-CM5A-LR & ocean, ocnBgchem, seaice, atmos & Institut Pierre-Simon Laplace & $\begin{array}{l}\text { Nat, Ant, GHG, SA, Oz, } \\
\text { LU, SS, Ds, BC, MD, OC, } \\
\text { AA }\end{array}$ & $1850-2005$ \\
\hline
\end{tabular}

CPD

$9,6161-6178,2013$

Discrepancies of surface temperature trends in the CMIP5 simulations

L. Zhao et al.

\section{Title Page}

\section{Abstract}

Introduction

Conclusions

References

Tables

Figures

14

$>$ I

4

Back

ck

Close

Full Screen / Esc

Printer-friendly Version

Interactive Discussion 


\section{CPD}

\section{$9,6161-6178,2013$}

\section{Discrepancies of} surface temperature trends in the CMIP5 simulations

Table 2. Correlation of the running linear trend between HadCRUT4 data set and the CMIP5 models and the NASA-GISS (italics indicate a correlation coefficient above 0.4, representing the significant test at $99 \%$ confidence level; bold indicates a negative correlation.

\begin{tabular}{|c|c|c|c|c|c|c|c|c|c|c|c|c|c|c|}
\hline & $\mathrm{GL}$ & $\mathrm{NH}$ & $\mathrm{SH}$ & Tropics & Arctic & Antarctic & US & SA & $\mathrm{AU}$ & $\mathrm{RU}$ & NAF & SAF & EU & $E A$ \\
\hline CESM1 & 0.37 & 0.47 & 0.13 & 0.19 & .29 & 0.18 & 0.38 & 0.04 & 0.27 & 0.10 & 0.49 & .32 & 0.37 & 0.28 \\
\hline CGCM3 & 0.31 & 0.25 & 0.29 & 0.14 & 0.18 & 0.24 & 0.26 & 0.07 & 0.28 & 0.05 & 0.33 & 0.41 & 0.09 & 0.35 \\
\hline CNRMCM5 & 0.55 & 0.57 & 0.39 & 0.22 & 0.46 & 0.40 & 0.43 & 0.09 & 0.37 & 0.25 & 0.43 & 0.42 & 0.21 & 0.40 \\
\hline GISSE2H & 0.51 & 0.66 & 0.40 & 0.22 & 0.35 & 0.19 & 0.47 & 0.08 & 0.38 & 0.14 & 0.44 & 0.36 & 0.38 & 0.56 \\
\hline GISSE2R & 0.51 & 0.62 & 0.34 & 0.23 & 0.29 & 0.34 & 0.49 & 0.14 & 0.38 & 0.20 & 0.43 & 0.38 & 0.45 & 0.60 \\
\hline IPSL & 0.47 & 0.54 & 0.38 & 0.21 & 0.29 & 0.31 & 0.43 & 0.03 & 0.24 & 0.04 & 0.41 & 0.33 & 0.15 & 0.59 \\
\hline MIROCESM & 0.36 & 0.55 & 0.33 & 0.17 & 0.44 & -0.22 & 0.36 & 0.26 & 0.15 & 0.29 & 0.39 & 0.28 & 0.38 & 0.54 \\
\hline MPIESMP & 0.47 & 0.50 & 0.40 & 0.32 & -0.02 & 0.22 & 0.35 & 0.13 & 0.44 & -0.12 & 0.26 & 0.18 & 0.11 & 0.45 \\
\hline MPII & 0.41 & 0.48 & 0.20 & 0.26 & 0.20 & -0.16 & 0.20 & 0.15 & 0.32 & 0.26 & 0.48 & 39 & 0.22 & 0.50 \\
\hline GFDLCM3 & 0.47 & 0.60 & 0.31 & 0.14 & 0.46 & 0.02 & 0.48 & 0.05 & 0.04 & 0.19 & 0.38 & .30 & 0.35 & 0.54 \\
\hline GFDLESM2G & 0.46 & 0.37 & 0.37 & 0.23 & 0.26 & 0.06 & 0.27 & 0.11 & 0.32 & 0.10 & 0.33 & 0.27 & 0.11 & 0.32 \\
\hline HadCM3 & 0.47 & 0.57 & 0.34 & 0.21 & 0.39 & 0.31 & 0.30 & 0.18 & 0.22 & 0.35 & 0.35 & 0.41 & 0.29 & 0.55 \\
\hline HadGEM2AO & 0.49 & 0.66 & 0.23 & 0. & 0.23 & -0.03 & 0.42 & -0.11 & 0.37 & 0.21 & 0.30 & 0.35 & 0.23 & 0.34 \\
\hline HadGEM2ES & 0.44 & 0.51 & 0.42 & & 0.38 & & 0.30 & 0.09 & 0.27 & 0.43 & 0.49 & 0.43 & 0.21 & 0.50 \\
\hline MIROC5 & 0.33 & 0.61 & 0.24 & -0.02 & 0.40 & -0.08 & 0.42 & -0.13 & -0.13 & 0.16 & 0.34 & 0.16 & 0.43 & 0.42 \\
\hline bcccsm 1 & 0.49 & 0.56 & 0.21 & 0.24 & 0.24 & -0.11 & 0.20 & 0.18 & 0.29 & 0.27 & 0.50 & 0.46 & 0.35 & 0.46 \\
\hline GISS & 0.94 & 0.93 & 0.84 & 0.97 & 0.92 & 0.59 & 0.88 & 0.92 & 0.89 & 0.9697 & 0.92 & 0.93 & 0.96 & 0.93 \\
\hline
\end{tabular}

L. Zhao et al.

\section{Title Page}

\section{Abstract}

Introduction

Conclusions

References

Tables

Figures

14

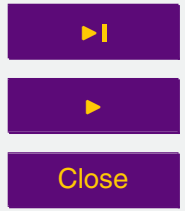

Back

Close

Full Screen / Esc

Printer-friendly Version

Interactive Discussion 


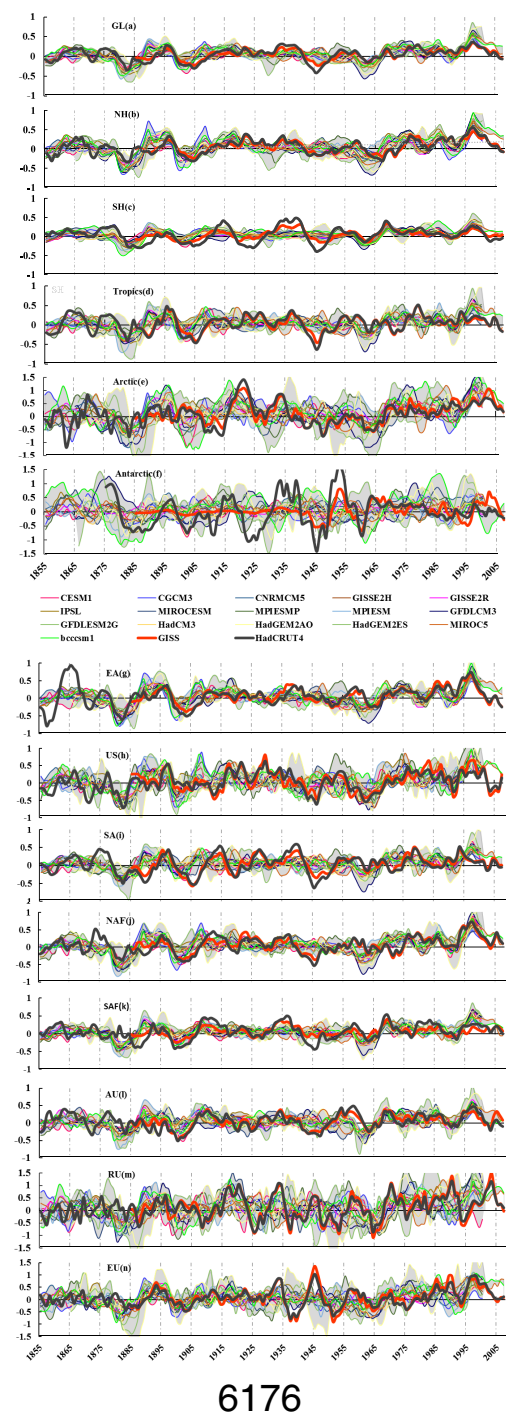

\section{CPD}

9, 6161-6178, 2013

Discrepancies of surface temperature trends in the CMIP5 simulations

L. Zhao et al.

Title Page

Abstract

Introduction

Conclusions

References

Tables

Figures

14

4

Back

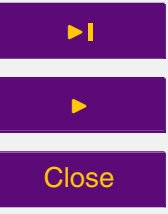

Full Screen / Esc

Printer-friendly Version

Interactive Discussion

(c) $\underset{\mathrm{BY}}{\mathrm{i}}$ 
Fig. 1. Running linear trends for $10 \mathrm{yr}$ moving time window from 1850 to 2012 (the period is 1850-2005 for most CMIP5 simulations) over the global and sub-regions. Grey shading represents the trends range from minimum to maximum in 16 selected CMIP5 models. The x-axis shows the middle year of the $10 \mathrm{yr}$ window, for example, 1855 denotes the trend in the period of 1850-1859. United States (US) $\left(25-50^{\circ} \mathrm{N}, 70-125^{\circ} \mathrm{W}\right)$, East Asia (EA) $\left(10-50^{\circ} \mathrm{N}, 75-150^{\circ} \mathrm{E}\right)$, Europe (EU) $\left(35-60^{\circ} \mathrm{N}, 0-35^{\circ} \mathrm{E}\right)$; Russia (RU) $\left(50-75^{\circ} \mathrm{N}, 35-160^{\circ} \mathrm{E}\right)$, Australia (AU) (10-40 $\mathrm{S}$, $\left.110-155^{\circ} \mathrm{E}\right)$, South America (SA) $\left(55^{\circ} \mathrm{S}-10^{\circ} \mathrm{N}, 35-80^{\circ} \mathrm{W}\right)$, South Africa (SAF) (0-30 $\mathrm{S}, 10$ $\left.40^{\circ} \mathrm{E}\right)$ and North Africa (NAF) $\left(0-30^{\circ} \mathrm{N}, 10-40^{\circ} \mathrm{E}\right)$.

\section{CPD}

9, 6161-6178, 2013

\section{Discrepancies of} surface temperature trends in the CMIP5 simulations

L. Zhao et al.

\section{Title Page}

\section{Abstract}

Introduction

Conclusions

References

Tables

Figures

14

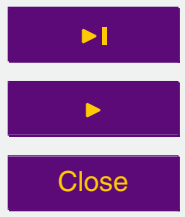

Back

Close

Full Screen / Esc

Printer-friendly Version

Interactive Discussion 
SPREAD AVERAGE

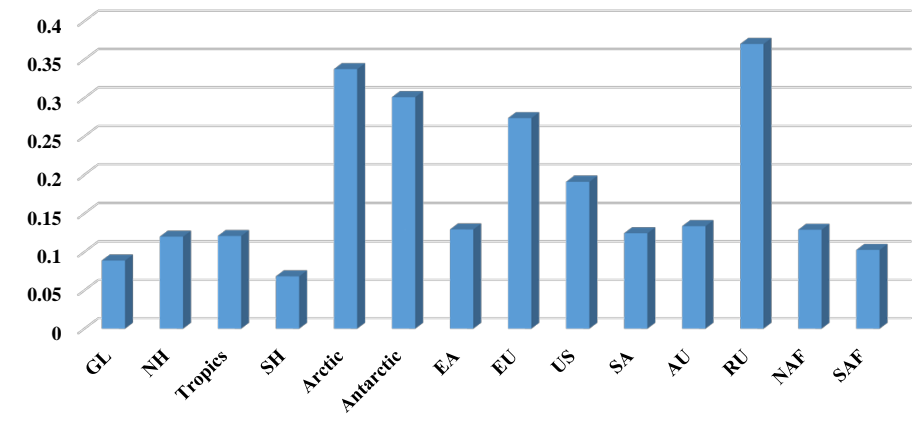

Fig. 2. Average spread of the temperature trend by region in the CMIP5 model simulations from 1860-2012.

\section{CPD}

9, 6161-6178, 2013

\section{Discrepancies of} surface temperature trends in the CMIP5 simulations

L. Zhao et al.

Title Page

Abstract

Introduction

Conclusions

References

Tables

Figures

14

4

Back

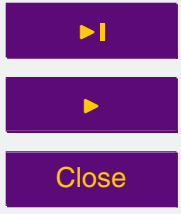

Full Screen / Esc

Printer-friendly Version

Interactive Discussion 